\title{
A REVIEW OF BENZOPYRAN DERIVATIVES IN PHARMACOTHERAPY OF BREAST CANCER
}

\author{
KUMAR PIYUSH ${ }^{1,2}$, SINGH KULDEEP ${ }^{1 *}$, RAHMAN Md. AZIZUR ${ }^{1}$, HASAN SYED MISBAHUL ${ }^{1}$, WAL PRANAY²
}

${ }^{1}$ Faculty of Pharmacy, Integral University, Lucknow - 226 026, Uttar Pradesh, India. ${ }^{2}$ Department of Pharmacy, Pranveer Singh Institute of Technology, Kanpur - 209 305, Uttar Pradesh, India. Email: kuldeep@iul.ac.in

Received: 19 March 2018, Revised and Accepted: 16 April 2018

ABSTRACT

One of the naturally occurring compounds containing oxygen moiety is benzopyran. Depending on its substitution pattern, different biological effects are shown. The benzopyran ring system is present in many natural products (such as genistein, hesperidin, and warfarin) as well as synthetic products. It displays pharmacological properties such as antitumor, anti-HIV, antimicrobials, anti-inflammatory, and anticoagulants. The sufficient literature support and the fact that benzopyran has potential as a pharmacophore particularly as anti-breast cancer, etc, current research seemed pertinent keeping in view the mechanism of anti-breast cancer activity. Therefore, the objective of this review is to focus on important benzopyran analogs with anti-breast cancer activity and highlight their mechanisms of action.

Keywords: Anticancer, Benzopyran, Breast cancer, Estrogen, Estrogen receptor

(C) 2018 The Authors. Published by Innovare Academic Sciences Pvt Ltd. This is an open access article under the CC BY license (http://creativecommons. org/licenses/by/4. 0/) DOI: http://dx.doi.org/10.22159/ajpcr.2018.v11i7.26017

\section{INTRODUCTION}

Benzopyran, a bicyclic heterocyclic system, constitutes a privileged structure in medicinal chemistry. Benzopyran unit is present in many natural products as found in $\alpha$-tocotrienol, $\gamma$-tocotrienol, $\delta$-tocotrienol, and tocopherol (Vitamin E) carrying phytyl chain on the pyran ring [1]. They are present in pigments in leaves and in various food sources such as in olive oil, red wine, fruits, and tree [2]. Some naturally occurring benzopyran derivatives include warfarin (1), genistein (2), nebivolol (3), hesperidin (4), and umbelliferone (5). Thus, benzopyran constitutes the basic backbone of various compounds such as coumarins (6), chroman (7), xanthenes (8), polyphenols like flavonoid (9), and anthocyanin (10). The two isomers of benzopyran are present which differ by the orientation of the fusion of the two ring systems contrasted to the oxygen which results in $2 \mathrm{H}-1$-benzopyran (chromene, 11) and 2-benzopyran (isochromene, 12; Fig. 1).

Literature reveals that benzopyrans are important chemical synthon, associated with a broad range of biological effects including antioxidant $[3,4]$, anti-HIV $[5,6]$, neuroprotective $[7,8]$, antiepileptic $[9,10]$, antimicrobial $[11,12]$, antidiabetic $[13,14]$, antihypertensive $[15,16]$, and anticancer agents $[17,18]$. Among the diverse biological activities of benzopyrans, breast cancer is one of the most intriguing since the discovery of ormeloxifene [19], KBU2046 (Phase II) [20], and B43-genistein [21]. Therefore, many benzopyrans have contributed to the search for new anti-breast cancer agents.

\section{BENZOPYRAN AND BREAST CANCER}

Breast cancer is considered as the most commonly diagnosed cancers and is the second leading cause of cancer death among women in India. The mechanism of breast cancer progression is related with cell proliferation and apoptotic cell death (Fig. 2) [22]. Although chemotherapy is widely recognized as the mainstay of cancer therapy, undesirable side effects limited the use of anticancer drugs in chemotherapeutics [23].

\section{Selective estrogen receptor modulators (SERMs)}

Estrogens considered playing a valuable role in the development and progression of breast cancer having hormone dependency. Therefore, estrogens and ERs are recognized as significant molecular targets for breast cancer. Estrogens have diverse positive effects on various body parts, especially on brain, heart, liver, bone, and vagina. The prolonged estrogen exposure may have some serious negative effects such as increased risk of breast and uterine cancers $[24,25]$. Therefore, ER blockers are the mainstay approach for breast cancer treatment.

SERMs include drugs which function as estrogen agonist in some target tissues whereas function as estrogen antagonists in others tissues. Genistein works as a SERM and also being tested as a preventive for breast cancer [26]. Kumar et al. synthesized a series of 2, 3, 4-triarylbenzopyrans and evaluated for its SERM activity. Compounds 13 and 14 displayed estrogen antagonistic activity having $73.91 \%$ and $69.24 \%$ inhibition, respectively. Compound 14 exhibited lowest inhibitory concentration $\left(\mathrm{IC}_{50}\right)$ at $6.97 \mu \mathrm{M}$ against MCF-7 cell line, while compound 15 exhibited lowest $\mathrm{IC}_{50}$ value of $5.6 \mu \mathrm{M}$ against MDA-MB-231 cell line despite they have low receptor binding affinity which may suggest that these compounds may possibly act by ERindependent mechanism. Compounds having free hydroxyl group at 2-position in phenyl ring resulted in increased estrogen antagonistic activity [27].

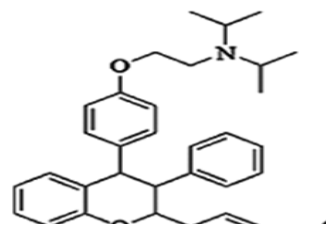<smiles>C/C=C(\C)C(c1ccc(OCCN(C(C)C)C(C)C)cc1)C(C)c1ccccc1</smiles>

Aromatase inhibitors (AIs)

The synthesis of estrogen involves aromatase (a cytochrome P450 enzyme complex) inhibition. This is encoded by the aromatase gene CYP19. Therefore, to decrease the level of estrogen, production affects AI. The aromatase enzyme is useful catalyst in the biosynthesis of estrogens from androgens. Inhibition of the aromatase enzyme is responsive to have significant action on the progress and expansion of hormone-dependent breast cancers $[24,28]$.

Bonfield et al. developed some new benzopyran derivatives (16 and 17) as potential AIs. Compounds 6-methoxy-3-phenylchroman-4-one (16) and 3-(pyridin-3-yl) chroman-4-one (17) showed potent activity with $\mathrm{IC}_{50}$ values of $2.4 \mu \mathrm{M}$ and $5.8 \mu \mathrm{M}$, respectively, in contrast to aromatase enzyme. However, compounds with functional groups such 


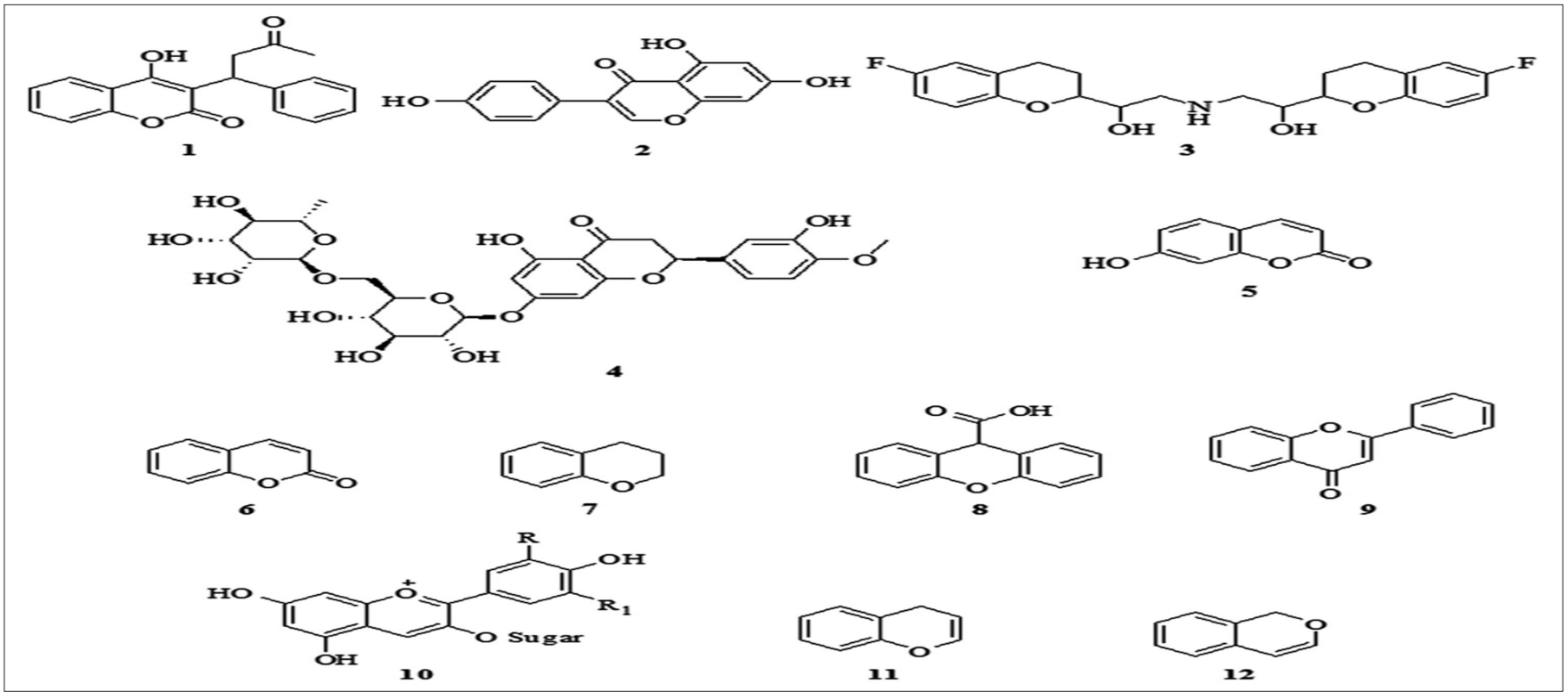

Fig. 1: Benzopyran-based heterocycles

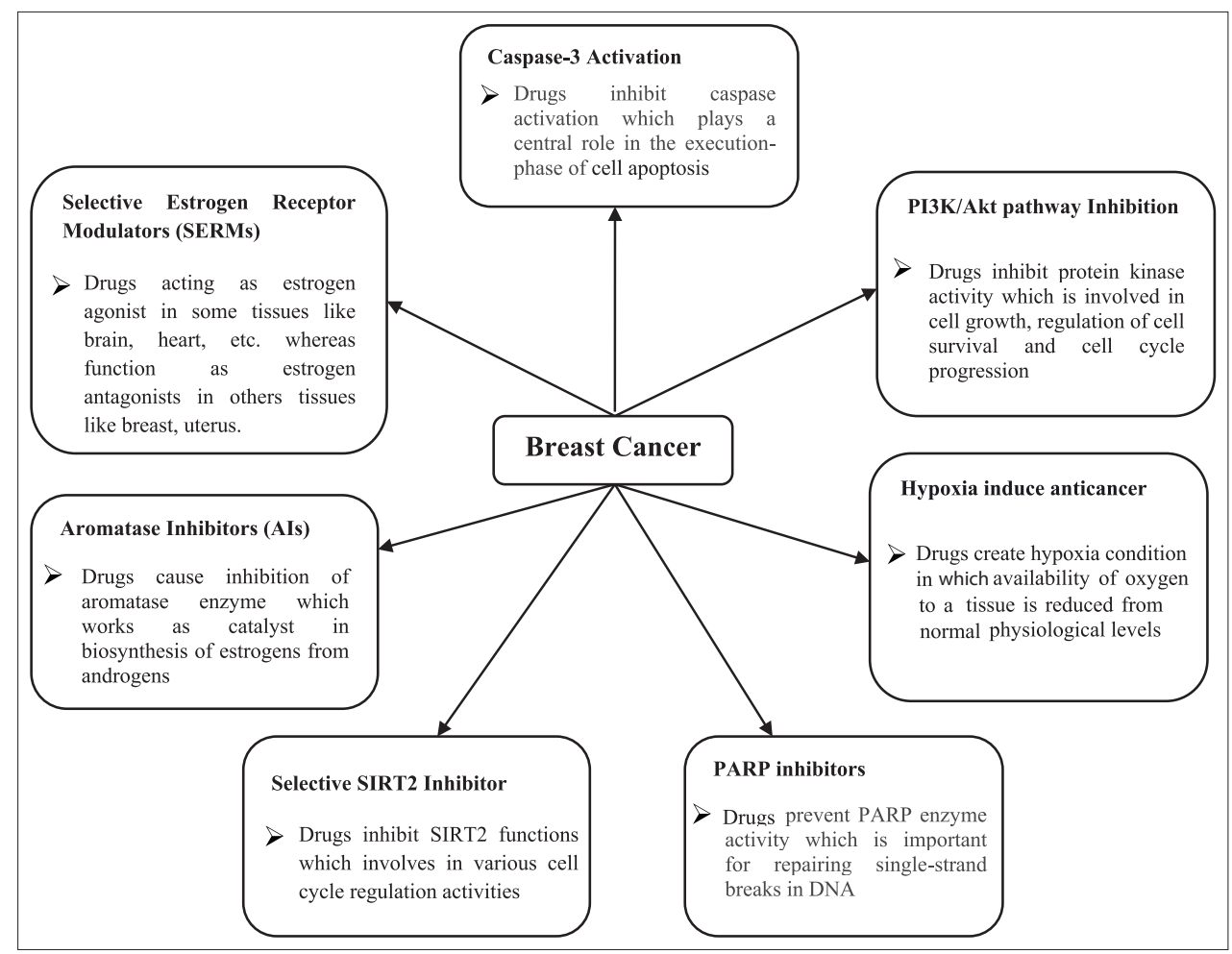

Fig. 2: The mechanism of action of anti-breast cancer drugs

as methoxy and pyridyl possessed potent activity against aromatase. It was proposed that non-planarity structural feature of the compound might involved in binding of enzyme and ligand. The binding mode analysis revealed that methoxy groups formed hydrogen bonds with aromatase molecule which might resulted in enhanced binding affinitv [29].<smiles>COc1ccc2c(c1)C(=O)C(c1ccccc1)CO2</smiles>

16<smiles>O=C1c2ccccc2OCC1c1cccnc1</smiles>

17

\section{Selective SIRT2 inhibitor}

SIRT2 belongs to the human sirtuin family and is responsible for $\mathrm{NAD+}$ (nicotinamide adenine dinucleotide)-dependent deacetylase activity. It is implicated as a potential drug target to combat cancer, neurodegeneration, and inflammation [30].

Seifert et al. reported the synthesis of a series of benzopyran4-ones having 2-position substitution by heterocyclic ring with increased hydrophilicity as SIRT2 inhibitors. Most active analogs (18 and 19) contained hydrogen bond accepting groups (pyridyl and 1,2,4-oxadiazole) and were recognized as selective SIRT2 inhibitors having low micromolar $\mathrm{IC}_{50}$ values. These compounds also exhibited antiproliferative activity in breast cancer and lung carcinoma in MCF-7 
and A549 cell lines, respectively. They worked by increasing acetylation level of $\alpha$-tubulin [31].<smiles>O=C1CC(CCc2cccnc2)Oc2c(Br)cc(Cl)cc21</smiles>

18<smiles>Cc1noc(CCC2CC(=O)c3cc(Cl)cc(Br)c3O2)n1</smiles>

Poly (adenosine diphosphate [ADP]-ribose) polymerase (PARP) inhibitors

PARP inhibitors are also called as poly ADP ribose polymerase inhibitor. It represents a group of pharmacological inhibitors. They are important for repairing single-strand breaks in DNA. They endeavor by preventing PARP enzyme activity, thereby preventing DNA damage repairmen, followed by stimulation of mitochondria which release apoptosisinducing factor and resulting in cell death. Therefore, PARP enzyme inhibition is becoming an attractive target for cancer therapy [32,33].

Singh et al. synthesized different 7,8-dimethoxy-3-hydroxy-2-(4methoxyphenyl)benzopyran-4-one derivatives and tested for their anticancer activity against MCF-7 cell line using SRB assay. Compounds displayed anticancer activity within the range of $\mathrm{IC}_{50} 2.58-34.86 \mu \mathrm{M}$. The most promising compound 20 activated apoptosis in MCF-7 cells and interfered with kinetics of tubulin polymerization. The molecular docking study was also performed for compound 20 which showed that it binds with ER- $\alpha$ [34].<smiles>COc1ccc(-c2oc3c(OC)c(OC)cc(OCCCC(=O)NCCc4ccccn4)c3c(=O)c2O)cc1</smiles>

\section{Hypoxia induce anticancer}

Hypoxia is a condition in which the availability of oxygen to a tissue is reduced from normal physiological levels. The stimulation of the hypoxia-inducible factor (HIF-1) pathway is associated with several types of cancer. Therefore, inhibition of the HIF-1 pathway is recognized as a viable approach to the development of anticancer agents [35].

Tan et al. performed a literature on natural products containing 2, 2-dimethylbenzopyran structure and prepared a combinatorial library of products. These natural products were evaluated for their inhibitory effects on hypoxic activation of an alkaline phosphatase reporter in human glioma cells. Compound 103D5R (21) was found to decrease HIF-1 $\alpha$ protein levels induced by hypoxia or cobaltous ions. Therefore, 103D5R works as an inhibitor of HIF-1 $\alpha$. The activity was also attributed on the duration of treatment. The mechanism involved the downregulation of HIF-1 $\alpha$ mRNA translation by 103D5R [36].<smiles>COc1c(C(C)n2cnc3ncccc32)ccc2c1C=CC(C)(C)O2</smiles>

21

Phosphatidylinositol-3 kinase (PI3K)/protein kinase (AKT) pathway inhibition

PI3Ks belongs to a family lipid kinase. The inositol ring 3'-OH group in inositol phospholipids undergoes phosphorylation by PI3Ks. Then, AKT comes in contact with the particular phospholipids, leading to its translocation to the inner membrane, and it is then subjected to phosphorylation and activation by PDK1 and PDK2. This activated AKT regulates the activity of various substrates involved in the cell growth, regulation of cell survival, and cell cycle progression. Many newer anticancer agents act by mechanisms involving PI3K/AKT pathway $[37,38]$.

Saxena et al. synthesized a series of benzopyran compounds and tested for its antiestrogen activity. The compound CDRI-85/287 (22) decreased the function of ER $\alpha$-dependent proliferation markers and ER $\beta$-dependent cell cycle progression markers. The EGFR activation was prevented by the compound 22, causing inhibition of PI-3-K/AKT pathway, leading to the induction of apoptosis. The mechanism of action included the antagonist effect of compound 22 with exogenous E2. The compound also showed low binding affinity due to the inexistence of hydroxyl group [39]

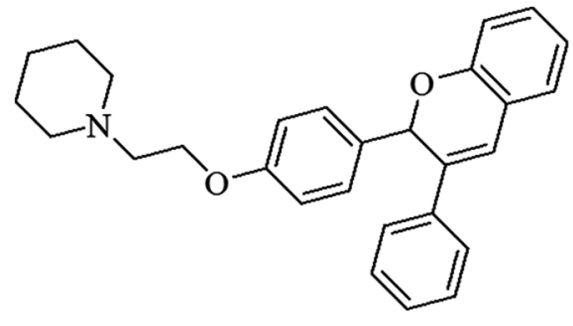

22

\section{Caspase- 3 activation}

Caspase- 3 is a caspase protein that interacts with caspase- 8 and caspase-9. It is encoded by the CASP3 gene. The CASP 3 protein is a member of cysteine-aspartic acid protease (caspase) family. Sequential activation of caspases plays a central role in the execution phase of cell apoptosis [40].

Sashidhara et al. synthesized coumarin-monastrol hybrid (23) and reported it as an anti-breast cancer agent. It was found that hybrid (23) was effective in breast cancer cells (MCF-7 and MDA-MB-231). It worked by inducing caspase- 3 activation and followed by apoptosis in both cell lines [41].<smiles></smiles>

\section{CONCLUSION}

As evident from numerous cited papers, the benzopyran scaffold is the building block of various chromans, coumarins, xanthones, and flavonoids present in various natural plants and pharmaceutical products. The overall conclusion is that benzopyran being one of the privileged heterocycles has shown a wide array of biological activities, particularly against cancer.

\section{ACKNOWLEDGEMENTS}

Mr. Piyush Kumar is thankful to Integral University, Lucknow, and Pranveer Singh Institute of Technology, Kanpur, for providing research facilities. Manuscript Communication Number (MCN): IU/R\&D/2018- MCN000263 office of research and development, Integral University, Lucknow.

\section{AUTHORS' CONTRIBUTION}

Concept, collection of data, and writing of the article - Piyush Kumar. Critical review of article - Kuldeep Singh, Md. Azizur Rahman, and Pranay Wal. Final approval of the article - Syed Misbahul Hasan. 


\section{CONFLICTS OF INTEREST}

The authors declare no conflict of interest.

\section{REFERENCES}

1. Pierpaoli E, Viola V, Pilolli F, Piroddi M, Galli F, Provinciali M. $\gamma$-and $\delta$-tocotrienols exert a more potent anticancer effect than $\alpha$-tocopheryl succinate on breast cancer cell lines irrespective of HER-2/neu expression. Life Sci 2010;86:668-75.

2. Middleton E, Kandaswami C, Theoharides TC. The effects of plant flavonoids on mammalian cells: Implications for inflammation, heart disease, and cancer. Pharmacol Rev 2000;52:673-751.

3. Lee H, Lee K, Jung JK, Cho J, Theodorakis EA. Synthesis and evaluation of 6-hydroxy-7-methoxy-4-chromanone- and chroman-2carboxamides as antioxidants. Bioorg Med Chem Lett 2005;15:2745-8.

4. Costantino L, Rastelli G, Gamberini MC, Vinson JA, Bose P, Iannone A, et al. 1-benzopyran-4-one antioxidants as aldose reductase inhibitors. J Med Chem 1999;42:1881-93.

5. Kraus GA, Mengwasser J, Maury W, Oh C. Synthesis of chroman aldehydes that inhibit HIV. Bioorg Med Chem Lett 2011;21:1399-401.

6. Tummino PJ, Ferguson D, Hupe L, Hupe D. Competitive inhibition of HIV-1 protease by 4-hydroxy-benzopyran-2-ones and by 4-hydroxy-6-phenylpyran-2-ones. Biochem Biophys Res Commun 1994;200:1658-64

7. Koufaki M, Kiziridi C, Alexi X, Alexis MN. Design and synthesis of novel neuroprotective 1,2-dithiolane/chroman hybrids. Bioorg Med Chem 2009; 17:6432-41

8. Hong KW, Kim KY, Lee JH, Shin HK, Kwak YG, Kim SO, et al. Neuroprotective effect of (2S,3S,4R)-N"-cyano-N-(6-amino-3, 4-dihydro-3-hydroxy-2-methyl-2-dimethoxymethyl-2H-benzopyran-4yl)-N'-benzylguanidine (KR-31378), a benzopyran analog, against focal ischemic brain damage in rats. J Pharmacol Exp Ther 2002;301:210-6.

9. Rawat P, Verma SM. Synthesis and pharmacological evaluation of 6-hydroxy-2,5,7,8-tetramethyl-N'-(2-oxoindolin-3-ylidene)chroman2-carbohydrazide derivatives as antimicrobial agents. J Chem Pharm Res 2016;8:149-54.

10. Bhat M, Siddiqui N, Khan S. Synthesis of novel 3-(4-acetyl-5h/methyl5-substituted phenyl-4,5-dihydro-1,3,4-oxadiazol-2-yl)-2h-chromen-2ones as potential anticonvulsant agents. Acta Pol Pharm 2008;65:235-9.

11. Patil RB, Sawant SD. Synthesis, docking studies and evaluation of antimicrobial and in vitro antiproliferative activity of 5h-chromeno 4,3d pyrimidin-2-amine derivatives. Int J Pharm Pharm Sci 2015;7:304-8.

12. Ahmed HA. Synthesis of some novel benzopyranes derivatives and evaluation their biological activity. Asian J Pharm Clin Res 2015;8:7-12.

13. Nayak Y, Hillemane V, Daroji VK, Jayashree BS, Unnikrishnan MK. Antidiabetic activity of benzopyrone analogues in nicotinamidestreptozotocin induced Type 2 diabetes in rats. Sci World J 2014. Article ID $854267: 1-12$

14. Unlusoy MC, Verspohl EJ, Erta R. Synthesis and antidiabetic activity of some new chromonyl-2, 4-thiazolidinediones. J Enzyme Inhib Med Chem 2010;25:784-9.

15. Bano M, Barot KP, Ahmed SM, Nikolova S, Ivanov I, Ghate MD. Benzopyran derivatives as cardio-selective ATP-sensitive potassium channel openers: A review. Mini Rev Med Chem 2013;13:1744-60.

16. Evans JM, Cassidy F. Benzopyran Derivatives, their Preparation and Anti-Hypertensive Pharmaceutical Compositions Containing them; 1983;EP 0126311 A3.

17. Rawat P, Verma SM. Design and synthesis of chroman derivatives with dual anti-breast cancer and antiepileptic activities. Drug Des Devel Ther 2016;10:2779-88

18. Rawat P, Verma SM. Docking studies of substituted chroman analogs at estrogen receptor. Asian J Pharm Clin Res 2015;8:88-92.

19. Lal J. Clinical pharmacokinetics and interaction of centchroman-a mini review. Contraception 2010;81:275-80.

20. Xu L, Farmer R, Haung X, Pavese J, Voll E, Irene O, et al. Discovery of a novel drug KBU2046 that inhibits conversion of human prostate cancer to a metastatic phenotype. Cancer Prev Res 2010;3:B58.
21. Chen CL, Levine A, Rao A, O’Neill K, Messinger Y, Myers DE, et al. Clinical pharmacokinetics of the CD19 receptor-directed tyrosine kinase inhibitor B43-genistein in patients with B-lineage lymphoid malignancies. J Clin Pharmacol 1999;39:1248-55.

22. Purushothaman A, Nandhakumar E, Sachdanandam P. Anticancer effect of shemamruthaa (a phytochemical formulation) on 7, 12-dimethylbenz(a)anthracene induced mammary carcinoma in rats. Asian J Pharm Clin Res 2012;5:101-7.

23. Solomon VR, Hu C, Lee H. Hybrid pharmacophore design and synthesis of isatin-benzothiazole analogs for their anti-breast cancer activity. Bioorg Med Chem 2009;17:7585-92

24. Kaushik S, Rikhi M. Docking and cytotoxicity studies of 2-vinylchromone derivatives on human breast cancer cell lines. Int $\mathrm{J}$ Pharm Pharm Sci 2015;7:113-7.

25. Ciocca DR, Roig V. Estrogen receptors in human nontarget tissues: Biological and clinical implications. Endocr Res 1995;16:35-62

26. Jordan VC. Antiestrogens and selective Estrogen receptor modulators as multifunctional medicines. Clinical considerations and new agents. J Med Chem 2003;46:1081-11.

27. Kumar S, Deshpande S, Chandra V, Kitchlu S, Dwivedi A, Nayak VL, et al. Synthesis and biological evaluation of 2,3,4-triarylbenzopyran derivatives as SERM and therapeutic agent for breast cancer. Bioorg Med Chem 2009; 17:6832-40

28. Muftuoglu Y, Mustata G. Pharmacophore modeling strategies for the development of novel nonsteroidal inhibitors of human aromatase (CYP19). Bioorg Med Chem Lett 2010;20:3050-64

29. Bonfield K, Amato E, Bankemper T, Agard H, Steller J, Keeler JM, et al. Development of a new class of aromatase inhibitors: Design, synthesis and inhibitory activity of 3-phenylchroman-4-one (isoflavanone) derivatives. Bioorg Med Chem 2012;20:2603-13.

30. Shah AA, Ito A, Nakata A, Yoshida M. Identification of a selective SIRT2 inhibitor and its anti-breast cancer activity. Biol Pharm Bull 2016;39:1739-42.

31. Seifert T, Malo M, Kokkola T, Engen K, Saxin MF, Wallén EA, et al. Chroman-4-one- and chromone-based sirtuin 2 inhibitors with antiproliferative properties in cancer cells. J Med Chem 2014:57:9870-88

32. McGlynn P, Lloyd B. Recombinational repair and restart of damaged replication forks. Nat Rev Mol Cell Biol 2002;3:859-70.

33. Yu SW, Andrabi SA, Wang H, Kim NS, Poirier GG, Dawson TW, et al. Apoptosis-inducing factor mediates poly(ADP-ribose) (PAR) polymerinduced cell death. Proc Natl Acad Sci U S A 2006;103:18314-9.

34. Singh S, Ahmad A, Raghuvanshi DS, Hasanain M, Agarwal K, Dubey V, et al. Synthesis of. 3,5-dihydroxy-7,8-dimethoxy-2-(4- methoxyphenyl) benzopyran-4-one derivatives as anticancer agents. Bioorg Med Chem Lett 2016;26:5322-7.

35. Brown JM, Wilson WR. Exploiting tumour hypoxia in cancer treatment. Nat Rev Cancer 2004;4:437-47.

36. Tan C, Noronha RG, Roecker AJ, Pyrzynska B, Khwaja F, Zhang Z, et al. Identification of a novel small-molecule inhibitor of the hypoxiainducible factor 1 pathway. Cancer Res 2005;65:605-12.

37. Vara JA, Casado E, Castro J, Cejas P, Belda-Iniesta C, GonzálezBarón M. PI3K/AKT signalling pathway and cancer. Cancer Treat Rev 2004;30:193-204.

38. Lee SH, Johnson D, Luong R, Sun Z. Crosstalking between androgen and PI3K/AKT signaling pathways in prostate cancer cells. J Biol Chem 2015;290:2759-68

39. Saxena R, Fatima I, Chandra V, Blesson CS, Kharkwal G, Hussain MK, et al. Benzopyran derivative CDRI-85/287 induces G2-M arrest in estrogen receptor-positive breast cancer cells via modulation of estrogen receptors $\alpha$ - and $\beta$-mediated signaling, in parallel to EGFR signaling and suppresses the growth of tumor xenograft. Steroids 2013;78:1071-86.

40. Feldmann H. Protease signalling in cell death: Caspases versus cysteine cathepsins. FEBS Lett 2007;581:2761-7.

41. Sashidhara KV, Avula SR, Sharma K, Palnati GR, Bathula SR. Discovery of coumarin-monastrol hybrid as potential antibreast tumorspecific agent. Eur J Med Chem 2013;60:120-7. 